\title{
Evaluation of different methodologies for the design of the wellfield in shallow geothermal systems
}

\author{
Evaluación de diferentes metodologías para el diseño del campo de captación de sistemas \\ geotérmicos someros
Cristina Sáez-Blázquez (D) 1 , Ignacio Martín-Nieto (iD) ', Arturo Farfán-Martín (iD)', Diego González-Aguilera (iD) 1 \\ ${ }^{1}$ Grupo TIDOP, Departamento de Ingeniería Cartográfica y del Terreno, Escuela Politécnica Superior de Ávila. Universidad \\ de Salamanca. Calle de Hornos Caleros 50, 05003. A. A. 37007. Ávila, España.
}

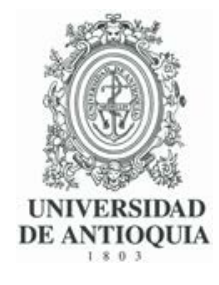

\section{CITE THIS ARTICLE AS:}

C. Sáez-Blázquez, I.

Martín-Nieto, A. Farfán-Martín

and D. González-Aguilera.

"Evaluation of different methodologies for the design of the wellfield in shallow geothermal systems", Revista Facultad de Ingeniería Universidad de Antioquia, no. 105, pp. 9-19, Oct-Dec 2022. [Online]. Available: https: //www.doi.org/10.17533/ udea.redin. 20210425

\section{ARTICLE INFO:}

Received: December 12, 2019 Accepted: October 15, 2021

Available online: October 15 , 2021

\section{KEYWORDS:}

Geothermal systems; GSHP; Climasoft; EED; GES-CAL

Sistemas geotérmicos; GSHP; Climasoft; EED; GES-CAL
ABSTRACT: Low enthalpy geothermal resources play an essential role in climate change mitigation. When ensuring the correct future operation of ground-source heat pump systems, an accurate design is mandatory. In this sense, different methodologies can be implemented. Although using sophisticated software constitutes the most optimal solution, its implementation is sometimes inviable in certain projects (the increase of the initial investment required is not justified in small plants). This work is focused on evaluating and comparing procedures used in the design of shallow geothermal systems. Thus, the research includes a simple method based on manual calculations, the Climasoft free application, Earth Energy Designer (EED) software, and the new geothermal tool GES-CAL developed by researchers from the TIDOP Research Group (University of Salamanca). The objective is to evaluate this new software and compare the results of all the detailed methodologies. This comparison derives from applying these tools in the calculation of the same case study la single-family house placed in Ávila, Spain). Results show that the easiest methods involve oversized well-field schemas that also mean higher initial investments. Regarding GES-CAL, it is considered an accurate and valid alternative for the design of all heat exchanger configurations, especially for those installations placed in the region of Ávila. However, EED is recommended to calculate high-power geothermal systems that require an exhaustive analysis of the ground and the heat carrier fluid behaviour.

RESUMEN: Los recursos geotérmicos de baja entalpía juegan un papel esencial en la mitigación del cambio climático. Para garantizar el funcionamiento de los sistemas de bomba de calor, es obligatorio un diseño preliminar preciso. A la hora diseñar estas instalaciones es posible implementar metodologías con diferentes grados de precisión. Aunque el software más sofisticado constituye la mejor solución, su uso es inviable en determinados proyectos lel aumento de la inversión no está justificado en pequeños sistemas). Este trabajo se centra en evaluar procedimientos utilizados en el diseño de sistemas geotérmicos someros. La investigación incluye el método más simple basado en cálculos manuales, la aplicación gratuita Climasoft, el software Earth Energy Designer (EED) y la herramienta GES-CAL desarrollada por investigadores del Grupo de Investigación TIDOP (Universidad de Salamancal. El objetivo es evaluar este software y comparar los resultados de todas las metodologías detalladas. Esta comparación deriva de la aplicación de estas herramientas sobre el mismo caso de estudio ledificio unifamiliar emplazado en Ávila, España). Los resultados muestran que los métodos más sencillos involucran esquemas de captación sobredimensionados que conllevan inversiones más altas.

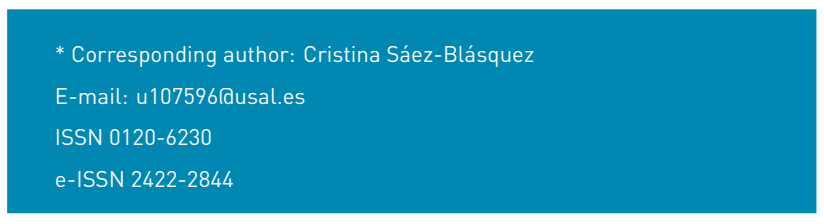


En cuanto a GES-CAL, se considera una alternativa precisa para el diseño de todas las configuraciones de intercambiadores, especialmente instalaciones ubicadas en la región de Ávila.Se recomienda EED para el cálculo de sistemas geotérmicos de alta entalpía que requieren un análisis exhaustivo del comportamiento del fluido de trabajo.

\section{Introduction}

Global warming, one of the main concerns worldwide, is fostering the replacement of fossil fuels with promising renewable energy sources [1]. In this context, ground source heat pumps are gaining increasing importance due to the reduction of greenhouse gas emissions and the lower operational costs [2-4]. These technologies that directly use the ground heat are considered among the most sustainable choices for space heating $[5,6]$. Heat is extracted from the ground at a relatively low temperature, which is then increased through the heat pump and used in a heating system, with higher performance than the traditional air-source heat pump systems [7, 8]. Depending on the method of operating the fluid, these systems are commonly classified as open or closed systems. In the first place, open systems use groundwater as heat carrier fluid brought to the heat pump through an extraction borehole. Closed systems are characterized by the use of a mixture of water-glycol as working fluid and heat exchangers located in the underground leither in a horizontal, vertical or oblique fashion) [9].

Focusing on the last group (closed systems) for being the most frequent configuration, numerous analytical and simulation models try to provide results in the prediction of the heat transfer in this kind of installations [10-12]. The correct design of the heat exchangers is crucial to ensure the future operation of the system. PC-programs constitute a quick and reasonably sound dimensioning of ground-source heat pump systems [13-15]. In this context, Earth Energy designer (EED) constitutes one of the most accessible and user-friendly programs for an accurate design of the final geothermal schema. Despite the large number of advantages of EED software, it only enables the dimensioning of vertical, closed-loop systems; that is to say, horizontal and helical heat exchanger configurations are not included $[16,17]$.

With the aim of dealing with a broader range of possibilities, this research also considers using a new approach, GES-CAL software, which allows the design of all the possible heat exchanger configurations. The development of this new tool is based on the results and conclusions of already published research works [18-24].

The aim of the present research is to evaluate and compare both geothermal programs (EED and GES-CAL), as well as additional simpler procedures that could be useful when the other tools are unavailable. A certain case study with identical input data will be the starting point for implementing all the methodologies mentioned above. The novelty of this work derives from the combination of approaches with different precision rates and the identification of their influence in the final design of a low enthalpy geothermal system. In this way, the following sections describe, for each method, the calculation, and design of a shallow geothermal system to supply the energy demand of space. Sections 2 and 3 describe the process of calculation of all the approaches, section 4 presents the principal results, and finally, section ?? contains the main conclusions of the manuscript. It should be mentioned that this work is an extension of the one published in ICSC-CITIES2019 [25].

\section{Materials and method}

As mentioned in the introductory section, the objective of this work is the comparison of certain specific procedures and software used for the design of shallow geothermal systems. All these methodologies are described below as well as the particular case in which they are implemented.

\subsection{Brief description of the geothermal calculation procedures}

\section{Manual calculation}

One of the simplest procedures used to estimate the drilling length of a vertical GSHP system is based on the guidelines of the German regulation VDI 4640 [26]. As shown in Table 1, this regulation describes the specific thermal power of the ground for different rocky materials.

Table 1 Specific thermal power for different geological formations according to VDI 4640

\begin{tabular}{c|cc}
\hline & Specific thermal power $(\mathbf{W} / \mathbf{m})$ & \\
\hline Ground materials & $\mathbf{1 8 0 0 h}$ & $\mathbf{2 4 0 0 h}$ \\
\hline Gravel, sand, dry sand & $<25$ & $<20$ \\
Gravel, sand, wet sand & $65-80$ & $55-85$ \\
Gravel and sand aquifers & $80-100$ & $80-100$ \\
Wet clay, silt & $35-50$ & $30-40$ \\
Limestones rocks & $55-70$ & $45-60$ \\
Sandstones & $65-80$ & $55-65$ \\
Granite formations & $65-85$ & $55-70$ \\
Basalts formations & $40-65$ & $35-55$ \\
Gneiss & $70-85$ & $60-70$ \\
\hline
\end{tabular}

From the values of Table 1 and the energy demand of the building, the power of the heat pump evaporator is obtained from Equation 1.

$$
E_{p}=E_{d} \cdot(C O P-1) / C O P
$$


Where:

$E_{p}=$ Heat pump evaporator power (W)

$E_{d}=$ Space energy demand $(\mathrm{W})$

$C O P=$ heat pump coefficient of performance

The total drilling length of the system is then calculated as shown in Equation 2. This procedure only considers the use of single vertical $U$-tube heat exchangers.

$$
D_{l}=E_{p} / G_{p}
$$

Where:

$D_{l}=$ Total drilling length $(\mathrm{m})$

$G_{p}=$ Ground thermal power $(\mathrm{W} / \mathrm{m})$, included in Table 1

\section{Open source tools}

An additional possibility for the design of low enthalpy geothermal systems is the use of open-source tools that provide an approximate configuration of the well field. In this context, this work considers the online computing application Climasoft developed by Tachyon. In the following Figure 1, it is possible to observe the main window of the mentioned tool.

By introducing the heat pump power and the thermal conductivity of the ground, Climasoft directly provides the heat exchanger length for different simple- $U$ and double- $U$ configurations.

\section{Earth Energy Designer (EED)}

This PC program, developed by Blocon (Buildingphysics.com), is typically used in the design of vertical borehole heat exchangers in a ground-source heat pump system. Algorithms are derived from modeling studies with a numerical simulation model that results in analytical solutions of the heat flow with several possibilities of geometry and borehole patterns.

Firstly, the user must introduce a series of information about the ground, climatic conditions, space energy demand, and geothermal configuration. After the introduction of these initial data, EED software is capable of providing the final schema of the system in terms of borehole's number and drilling length, as well as the evolution of the temperature of the heat carrier fluid over the installation lifetime.

Table 2 includes the principal strengths and weaknesses detected when using EED software.

\section{GES-CAL}

GES-CAL software was created by members of the TIDOP Research Unit from the University of Salamanca
Table 2 Strengths and weaknesses of EED software

\begin{tabular}{|c|c|}
\hline \multicolumn{2}{|c|}{ EED software } \\
\hline Strengths & Weaknesses \\
\hline $\begin{array}{c}\text { Quick and easy use } \\
\text { Simulation of the ground and fluid behavior } \\
\text { over the system operation } \\
\text { Possibility of selecting different drilling } \\
\text { schemas } \\
\text { Different range of restrictions for the heat } \\
\text { carrier fluid temperature } \\
\text { Multiple solutions for the final well field } \\
\text { design }\end{array}$ & $\begin{array}{c}\text { Only vertical heat exchangers } \\
\text { It does not allow the calculation of the } \\
\text { space energy demand } \\
\text { Manual dimensioning of the heat pump } \\
\text { power } \\
\text { Standard properties for the geological } \\
\text { formations }\end{array}$ \\
\hline
\end{tabular}

(registration of the intellectual property 00/2019/3318) [27]. The development of this software is linked to the need to improve some particular modules of EED. Although its first version is specifically designed for the dimensioning of ground source heat pump systems in the region of Ávila (Spain), it can also be implemented in any other location.

Calculations of this PC program are based on the recommendations of IDAE (Institute for the diversification and energy savingl [28] and the results of previous research works [18-23]. The mentioned tool enables establishing the most appropriate working conditions concerning the ground thermal characterization, building energy demand, grouting material, and besides the fact that GES-CAL allows the selection of the most usual heat exchanger configurations (vertical, horizontal, or helical designs). The strengths and weaknesses of this tool are described in Table 3.

Table 3 Strengths and weaknesses of EED software

\begin{tabular}{|c|c|}
\hline \multicolumn{2}{|c|}{ GES-CAL software } \\
\hline Strengths & Weaknesses \\
\hline $\begin{array}{c}\text { Quick and easy use } \\
\text { Vertical, horizontal, and helical } \\
\text { configurations } \\
\text { ground } \\
\text { Enhanced thermal characterization of the } \\
\text { It allows the calculation of the space energy } \\
\text { demand } \\
\text { Automatic calculation of the final heat } \\
\text { pump power } \\
\text { Economic and environmental evaluation }\end{array}$ & $\begin{array}{l}\text { It does not provide simulations of the } \\
\text { fluid temperature evolution } \\
\text { The first version is specially developed } \\
\text { only for the region of Ávila (Spain) } \\
\text { Geological information limited to the } \\
\text { aforementioned area } \\
\text { It is not recommended for high power } \\
\text { installations, above } 70 \mathrm{~kW} \text { [29] }\end{array}$ \\
\hline
\end{tabular}

\subsection{Input data}

The application of all the methodologies described above has been focused on determining the geothermal schema to cover the heating demand of a particular case study. Table 4 shows the characteristics and conditions of the mentioned case.

\section{Calculation process}

Before implementing each of the geothermal procedures, the energy demand of the building must be defined, since 


\section{Climasoft \\ Cálculo y Software Energético}

zona de descarga de Software Climasoft para HVAC+R+E y GEOTERMIA I FCOMPREAHORA contacto |ayuda ?
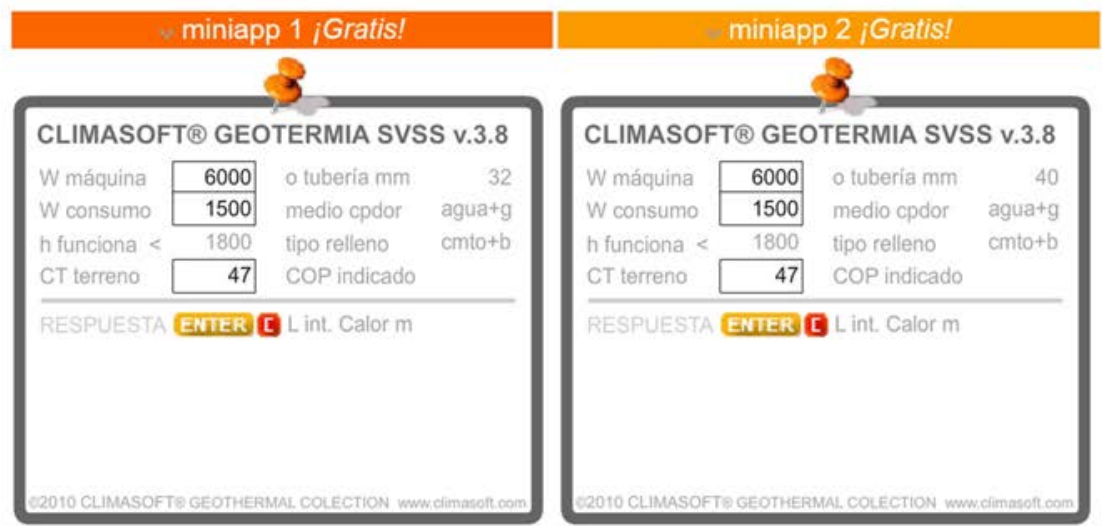

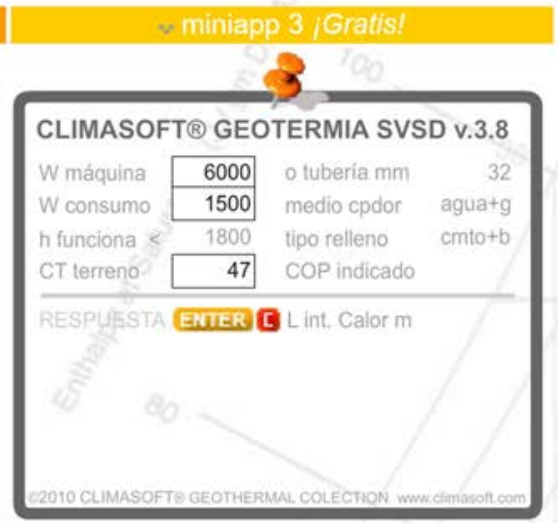

Figure 1 Climasoft main window
Table 4 Strengths and weaknesses of EED software

\begin{tabular}{l|l}
\hline \multicolumn{2}{c}{ Space information } \\
\hline Area & $100 \mathrm{~m}^{2}$ \\
Height & $4 \mathrm{~m}$ \\
Location & Ávila (Spain) \\
Building type & Single-family house \\
Year of construction & 2018 \\
Available ground dimension & $20 \times 20 \mathrm{~m}$ \\
Geology & Granitic formations \\
\hline
\end{tabular}

only GES - CAL software includes a specific module for its calculation. For this reason, the energy demand was estimated by the use of an external tool based on the regulation UNE-EN 13790:2011 [30]. Thus, as Figure 2 shows, the heating energy demand for the study building is $36.590 \mathrm{kWh} /$ year.

\subsection{Manual calculation}

According to Equations 1 of section 2, the heat pump evaporator power is expressed in Equation 3

$$
E_{p}=28232 W \cdot(4-1) / 4=21174 W
$$

Additionally, the total drilling length of the system is calculated by applying Equation 2 and considering a specific thermal power of $62.5 \mathrm{~W} / \mathrm{m}$ for granite rocks (Table 1). This calculation can be observed in Equation 4.

$$
d_{l}=21174 \mathrm{~W} / 60 \mathrm{~W} / \mathrm{m}=352.9 \mathrm{~m}
$$

\subsection{Climasoft}

Entering in the open-source application with the space energy demand, the heat pump COP, and the ground thermal conductivity, Climasoft directly provides the total length of the vertical heat exchanger (single or double U-tube). Results for both vertical configurations are included in Table 5.

Table 5 Results obtained using Climasoft application

\begin{tabular}{c|c}
\hline Schema & Heat exchanger length $(\mathbf{m})$ \\
\hline Single-U & 807 \\
Double-U & 628 \\
\hline
\end{tabular}

\subsection{EED}

When using EED software, the following steps must be carefully completed:

- Ground properties: EED provides standard thermal values for a set of geological formations. Since the building is located in a granitic environment, the parameters corresponding to this formation are selected. Regarding the ground superficial temperature, this software does not include the region of Ávila, so a similar climatic area must be selected.

- Heat exchanger configuration: the selection of the vertical design (simple-U, double-U, or coaxial), drilling conditions, and grouting material (Figure 3 ). 


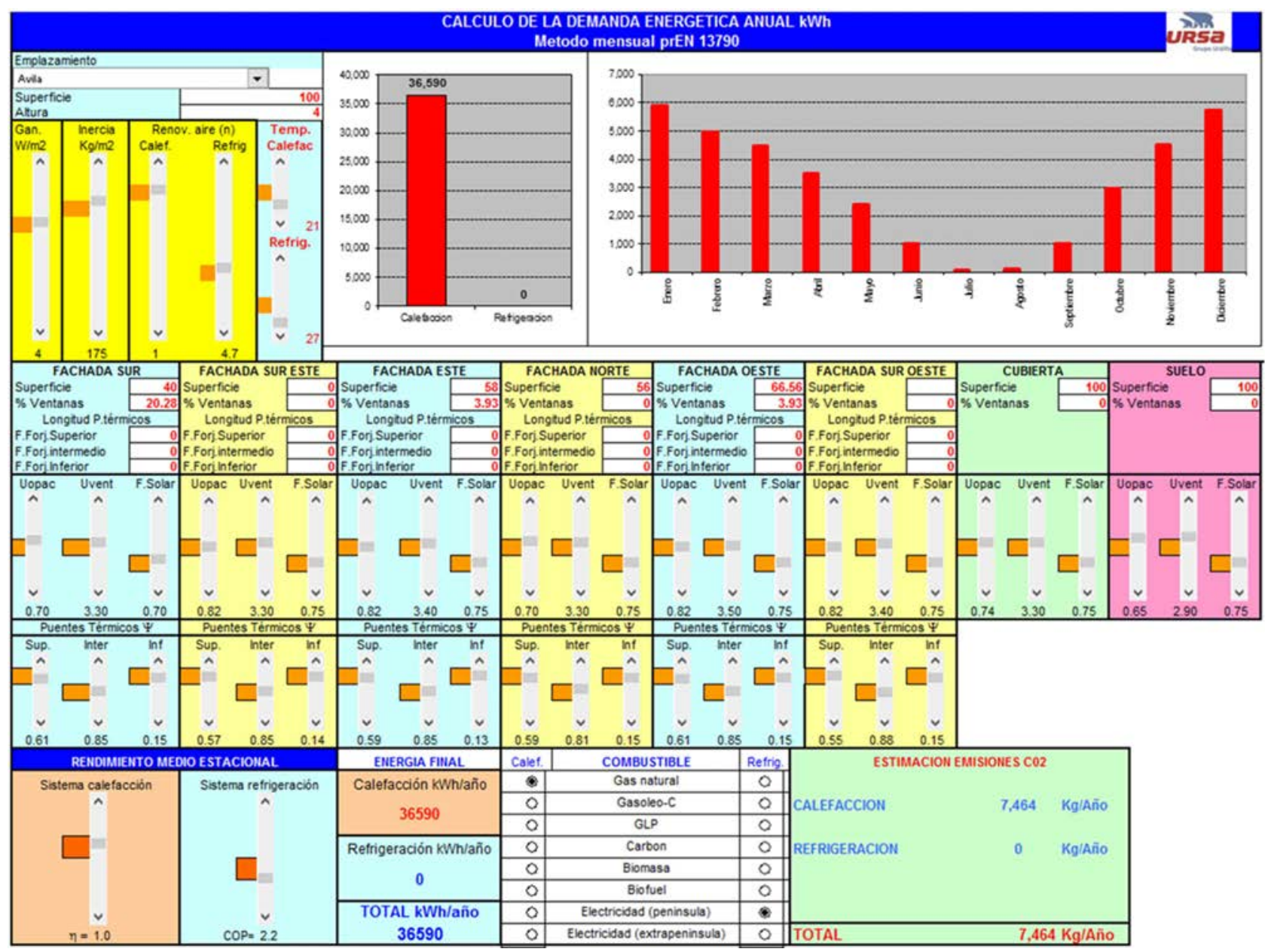

Figure 2 Calculation of the building energy demand

- Base and peak demand: introducing the building energy demand (previously calculated), EED provides the initial heat pump power that must be oversized by the user and introduced in the next step of the software (Figure 4).

- Schema of the ground-source heat pump system: the final result of EED software is the dimensioning of the drilling configuration, the number of boreholes, and total drilling length, as well as the evolution of the working fluid temperature (Figure 5). EED provides multiple drilling schemas, so the user selects one of them.

\subsection{GES-CAL}

GES-CAL software incorporates a module to calculate the space energy demand based on the area, height, orientation, and year of construction. In this way, the energy demand was automatically determined by this program and, as shown in Figure 6, taking the value of $36.680,80 \mathrm{kWh} /$ year.
- Heat pump dimensioning: GES-CAL can automatically define the final heat pump power without additional user calculations (Figure 7).

- Ground properties, heat exchangers, and grouting material: since GES-CAL was specifically designed for the region of Ávila llocation of the building of this research), it allows selecting the area of the province where the building is located (Figure 8). Once selected, GES-CAL automatically provides the thermal properties of the ground. In addition to the ground information, the user must define heat exchanger configuration and grouting material. Although GES-CAL considers the three most important designs, in this research, the vertical double U-tubes are selected to keep the same conditions in both programs. Grouting material is also the same in both assumptions.

- Well-field design: once all the initial data are defined, GES-CAL provides the final configuration of the well field, offering three possible alternatives (Figure 9). 


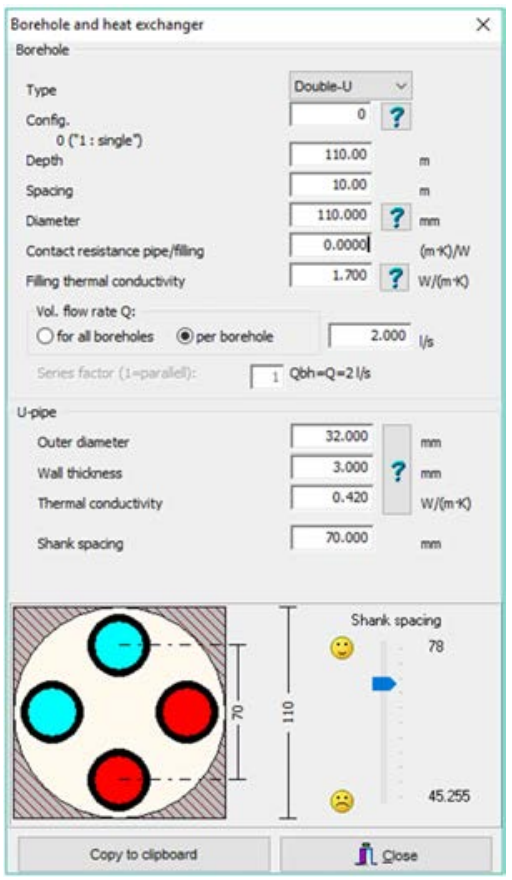

Figure 3 Heat exchanger configuration in EED

- Economic and environmental evaluation: GES-CAL can also estimate the initial investment of the system and its operational costs. It also compares the economic evolution of the ground-source heat pump system compared to other energy sources (Figure 10).

As shown in Figure 11, this software also calculates the emissions of greenhouse gases associated with the use of the geothermal system during the whole lifetime period and compares it with the emissions of other energy sources.

\section{Results and discussion}

This research solves the configuration of the well field in a ground-source heat pump system from different procedures: initially, a manual and easy procedure, the free application Climasoft, the commonly used EED, and the new software GES-CAL. From the implementation of all the mentioned methodologies (detailed in the previous section), the final schema of the geothermal system for the case presented in this work is included in the following Table 6.

Observing the results of the above Table 6, the final schema of the geothermal system is, in general terms, quite similar to applying EED or GES-CAL software, but it is significantly different for the simplest solutions. Going into more detail, the following subsections thoroughly compare the results of all the procedures from different points of view.
Table 6 Results obtained using Climasoft application

\begin{tabular}{ccccc}
\hline & $\begin{array}{c}\text { Manual } \\
\text { Calculation }\end{array}$ & Climasoft & EED & GES-CAL \\
\hline Number of boreholes & 2 & 2 & 1 & 1 \\
Borehole length & $88 \mathrm{~m}$ & $79 \mathrm{~m}$ & $101 \mathrm{~m}$ & $115 \mathrm{~m}$ \\
Total drilling length & $176 \mathrm{~m}$ & $158 \mathrm{~m}$ & $101 \mathrm{~m}$ & $115 \mathrm{~m}$ \\
Distance between boreholes & - & - & 0 & 0 \\
Heat pump nominal power & $5.08 \mathrm{~kW}$ & $5.08 \mathrm{~kW}$ & $5.08 \mathrm{~kW}$ & $5.08 \mathrm{~kW}$ \\
Minimum fluid temperature & $>0^{\circ} \mathrm{C}$ & $>0^{\circ} \mathrm{C}$ & $-6^{\circ} \mathrm{C}$ & $0^{\circ} \mathrm{C}$
\end{tabular}

\subsection{Well-field design}

Starting with the manual calculation, it requires the highest total drilling length followed by Climasoft, whose solution is also quite high. Considering the results of both procedures, the well field would be constituted by two boreholes.

In the case of EED and GES-CAL tools, only one borehole is required in the geothermal field. Both software applications propose lower drilling lengths Islightly higher when using GES-CAL). This fact derives from the different fluid temperature restrictions considered in the calculation of both programs. The high differences between the computer programs and the remaining simpler solutions derive from the complexity in the calculations of each procedure. Since PC programs include a large number of data about the ground, location, and other geothermal elements, their calculations are capable of offering results positively adjusted to the particular case. They also get highly accurate results because of the restriction on the working fluid temperature $\left(-6^{\circ} \mathrm{C}\right.$ in EED and $0^{\circ} \mathrm{C}$ in GES-CAL).

However, the easiest procedures are based on standard ground thermal conductivity values, and high working fluid temperatures (of above $0^{\circ} \mathrm{C}$ ). EED considers thermal standard thermal conductivity values from an internal database and GES-CAL provides measured values for those systems locates in the province of Ávila las the one of this work). For this reason, the results of the simplest approaches always involve higher drilling lengths given the lower level of knowledge on the system.

\subsection{Working fluid temperature}

The manual procedure and the Climasoft application consider that the minimum working fluid temperature never achieves values below $0^{\circ} \mathrm{C}$. Therefore, both methods require higher drilling lengths with the aim of keeping the fluid under these conditions.

Along the same lines, EED offers the possibility of analyzing the evolution of the heat carrier fluid temperature during a certain period (usually 25 years). This evaluation is essential to avoid ground freezing and to guarantee the right operation of the system in the 


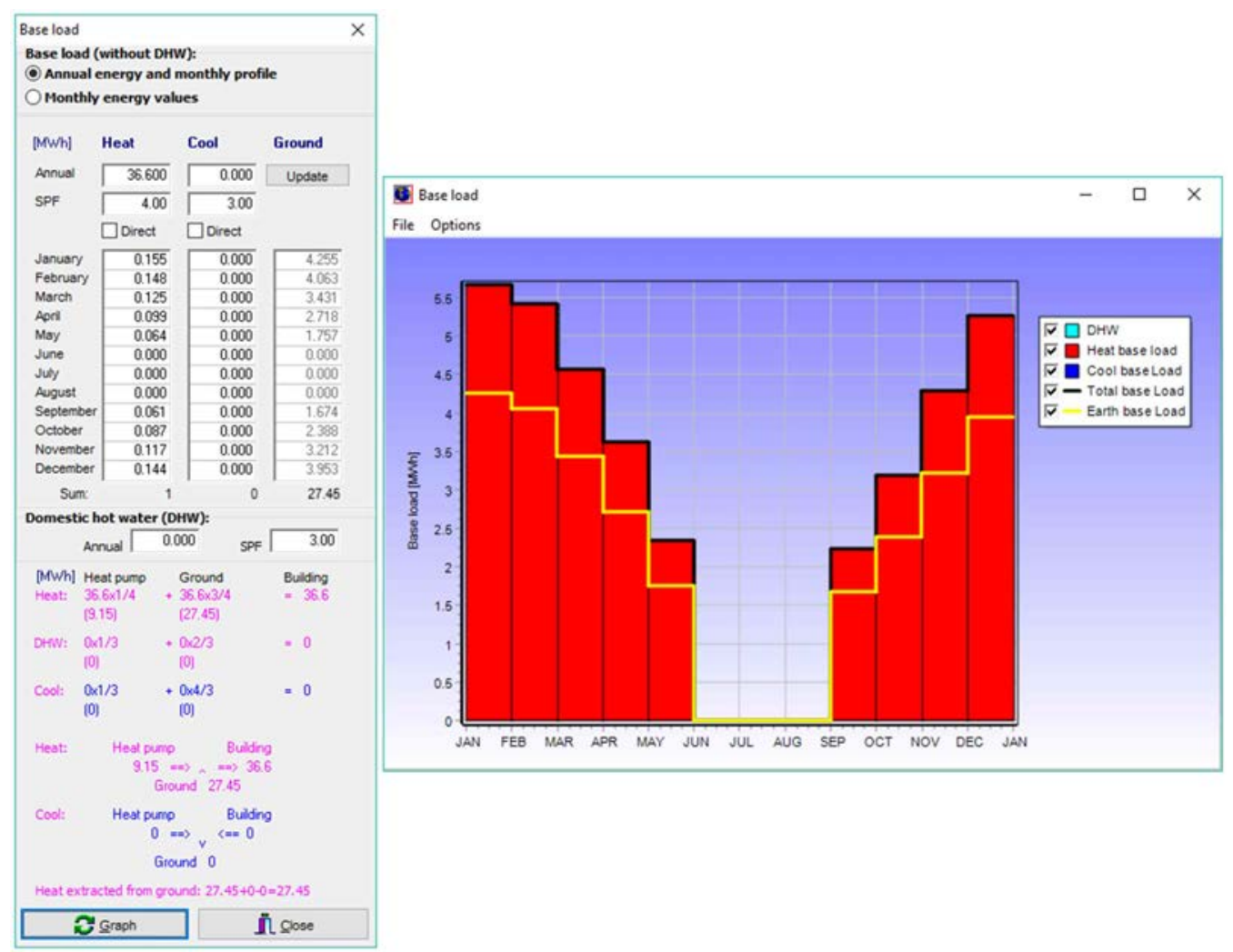

Figure 4 Base and peak demand in software EED

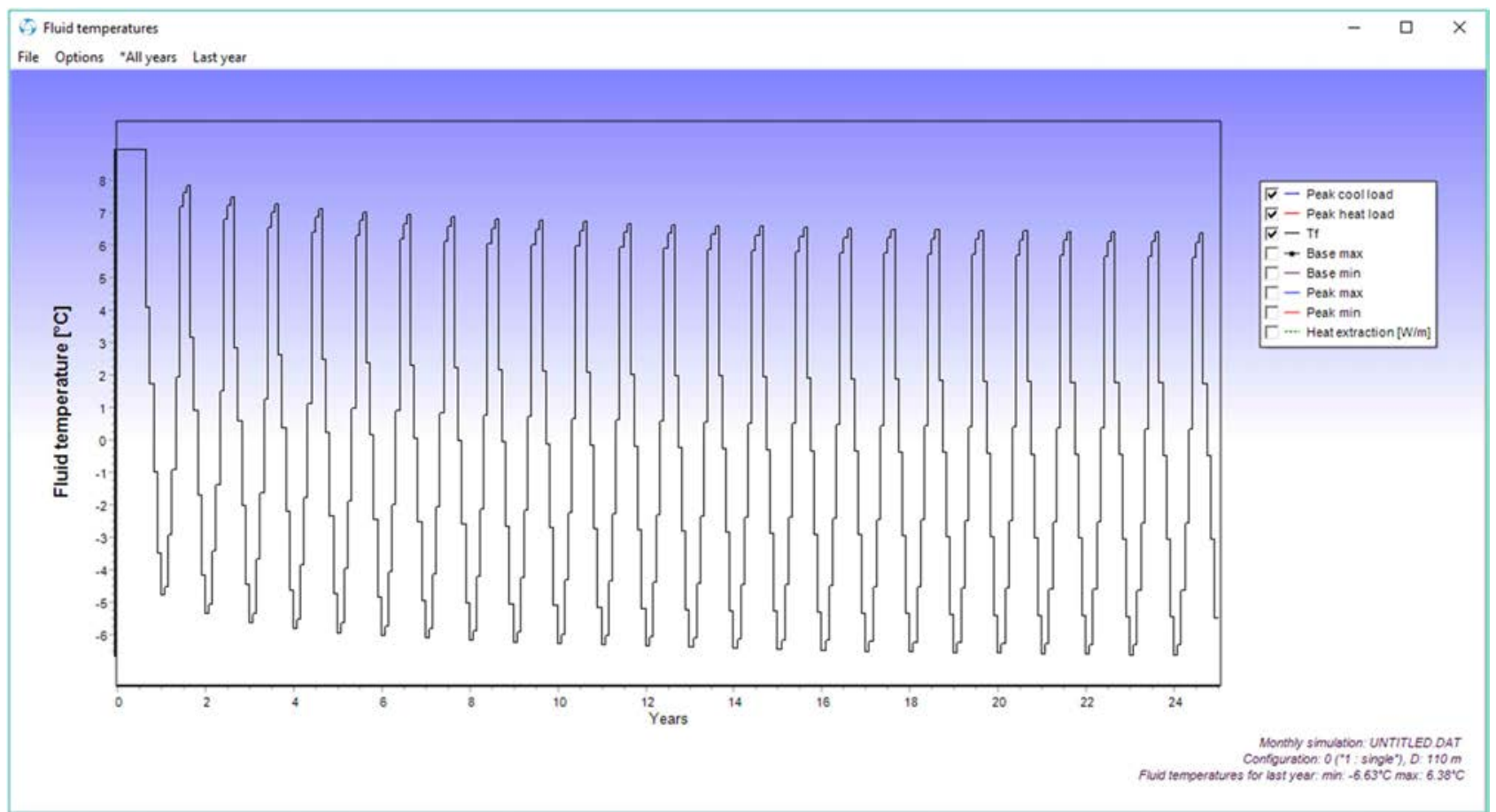

Figure 5 Evolution of the working fluid temperature in EED

mentioned period. For the case study presented in this research, the evolution of the fluid temperature allows knowing the minimum temperature value that the fluid will get over the system operation. Concerning GES-CAL 


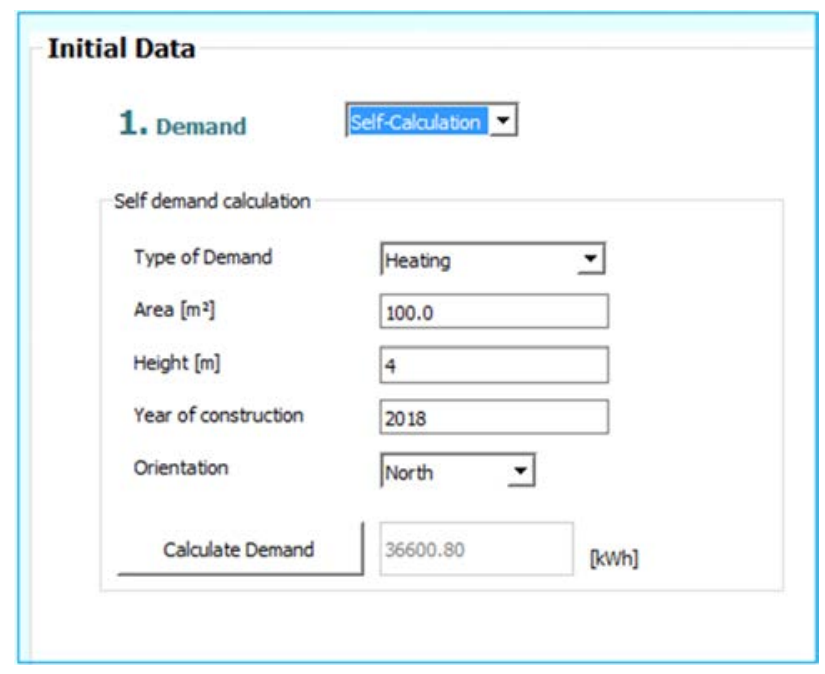

Figure 6 Module to calculate the energy demand of the building in GES-CAL

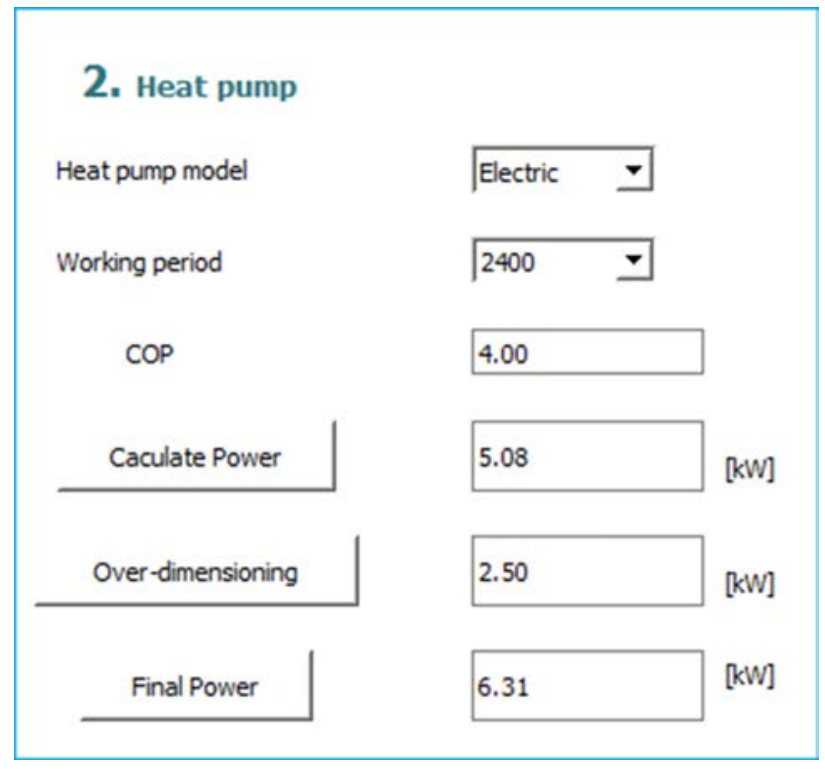

Figure 7 Heat pump dimensioning in GES-CAL

software, its calculations are based on a conservative minimum fluid temperature value $\left(0^{\circ} \mathrm{C}\right)$, ensuring, in this way, a proper working cycle of the installation without ground freezing. This restriction contributes to a higher dimensioning of the drilling length compared to EED results.

\subsection{Heat pump configuration}

In the case of the manual method and Climasoft, the heat pump power must be determined from the space energy demand.

As mentioned in the previous sections, in EED software,

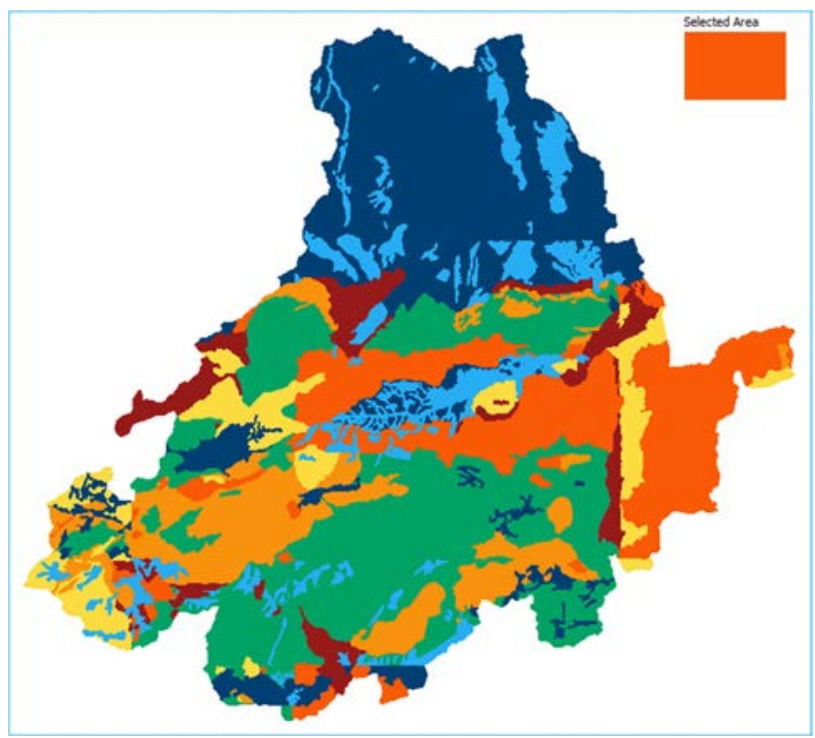

Figure 8 Selection of the area of study in GES-CAL

the user must define the final heat pump power of the system to complete the design of the well field. This final power needs to be oversized to deal with unexpected variations in the energy demand or errors in the global system operation. GES-CAL, however, includes a specific module that directly provides the final heat pump power required in the system, so the user does not need to perform extra calculations.

\subsection{Heat exchangers geometry}

The manual procedure can only be applied to geothermal systems constituted by single vertical U-tube heat exchangers, while, Climasoft is also able to design the system for both single and double $\mathrm{U}$ - tube configurations.

As explained above, EED considers the use of vertical heat exchangers Isingle and double $\mathrm{U}$-tubes and coaxial). Although these designs are the most common ones, horizontal, and helical configurations are also implemented in a large number of cases. For this reason, the new tool, GES-CAL, has been developed to enable the dimensioning of the geothermal system when using vertical, horizontal, or helical heat exchangers.

\section{Conclusions}

A new approach used for the design of closed, shallow geothermal systems is presented in this work. The validity of this new PC program (GES-CAL) has been evaluated through its application to a particular case study. Results of this software have been compared to the ones obtained from the use of three more procedures applied under the same initial conditions. The following statements can 


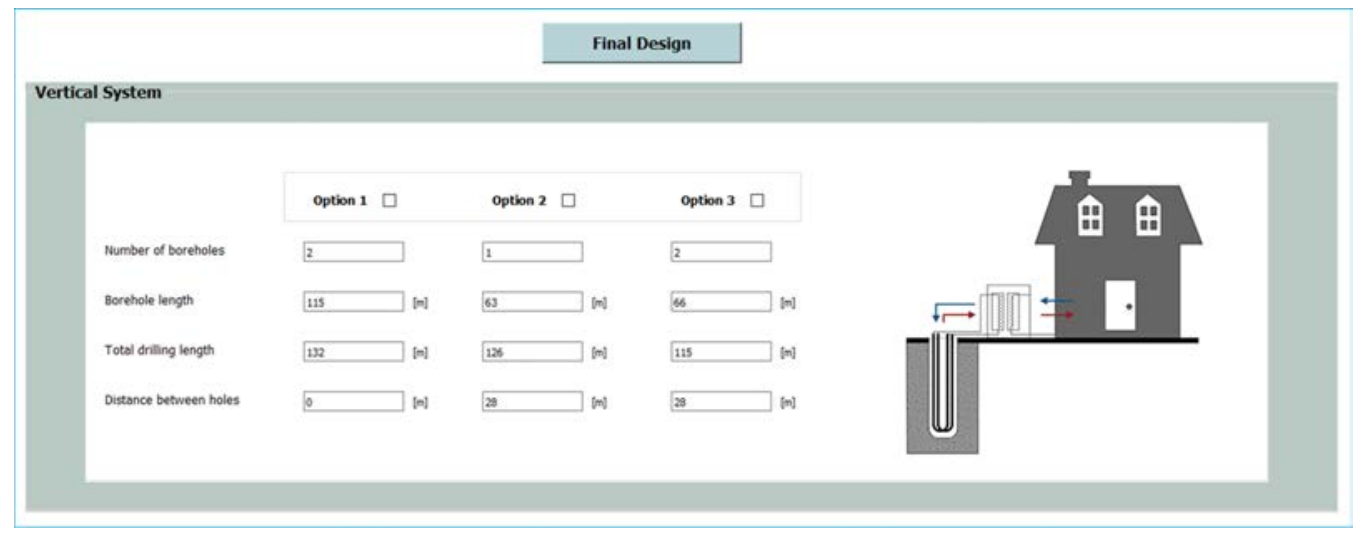

Figure 9 Final design of the well field using GES-CAL

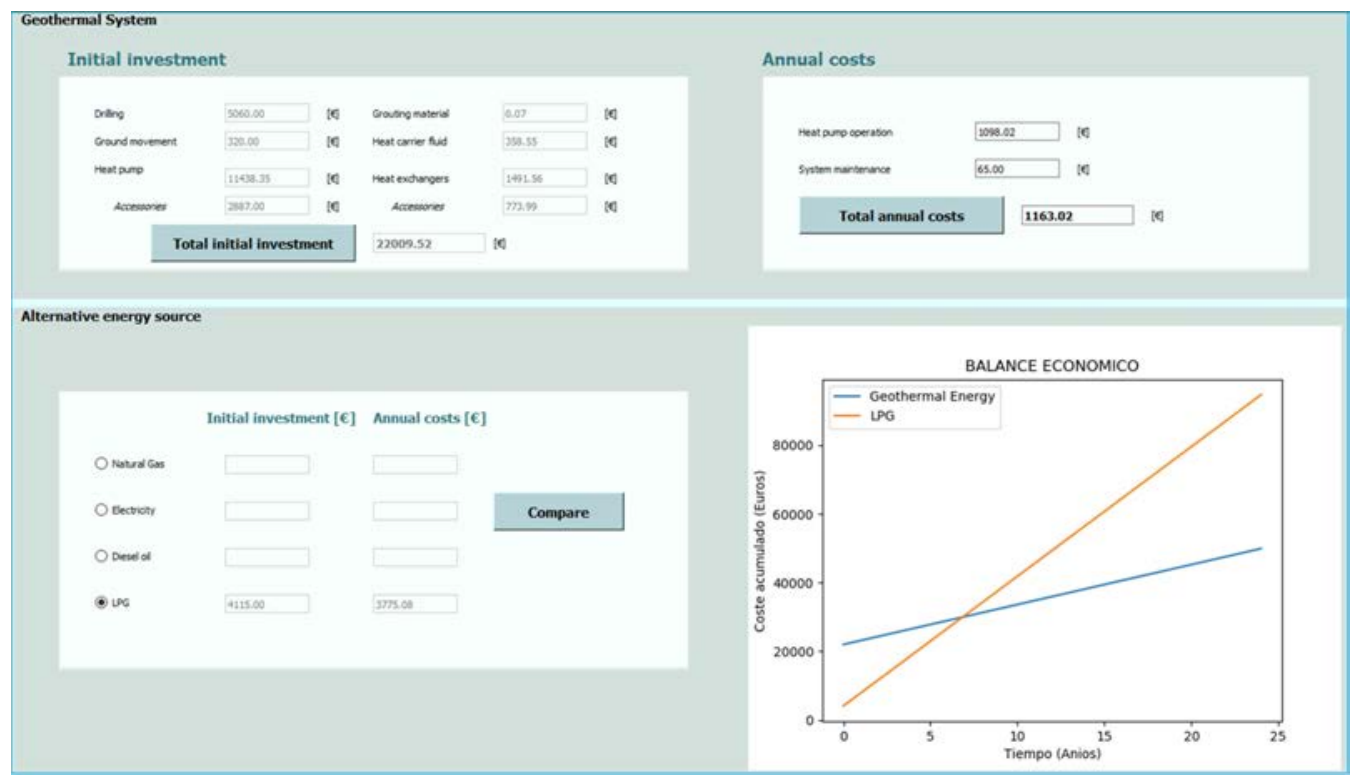

Figure 10 Economic evaluation of the ground-source heat pump system in GES-CAL

be deduced from the implementation of the mentioned methodologies:

- The use of the manual procedure or open-source applications as Climasoft allows the geothermal design from a general and ambiguous perspective. The reasonably low accuracy of these solutions involves an oversized well field that, in turn, means a fundamental increase of the global system investment.

- GES-CAL software constitutes an optimal solution for the design of shallow geothermal systems, especially for those located in the region of Ávila. The accuracy of the results obtained from the use of this program is considerably high since calculations derive from the thermal characterization of the ground in that region.

- Although GES-CAL does not enable the simulation of the working fluid temperature, calculations consider a conservative temperature restriction that ensures a proper response of the ground during the whole system operation.

- The range of use of GES-CAL allows the dimensioning of all the most frequent heat exchangers configurations that EED software does not include.

- In addition, GES-CAL offers the possibility of evaluating the geothermal systems in economic and environmental terms. It calculates the initial investment of the installation, the operational costs, and the greenhouse gases emission associated with its use. Finally, this module is capable of comparing the geothermal systems concerning alternative energy sources.

- GES-CAL means an intuitive and quick tool that facilitates and simplifies the dimensioning of shallow 


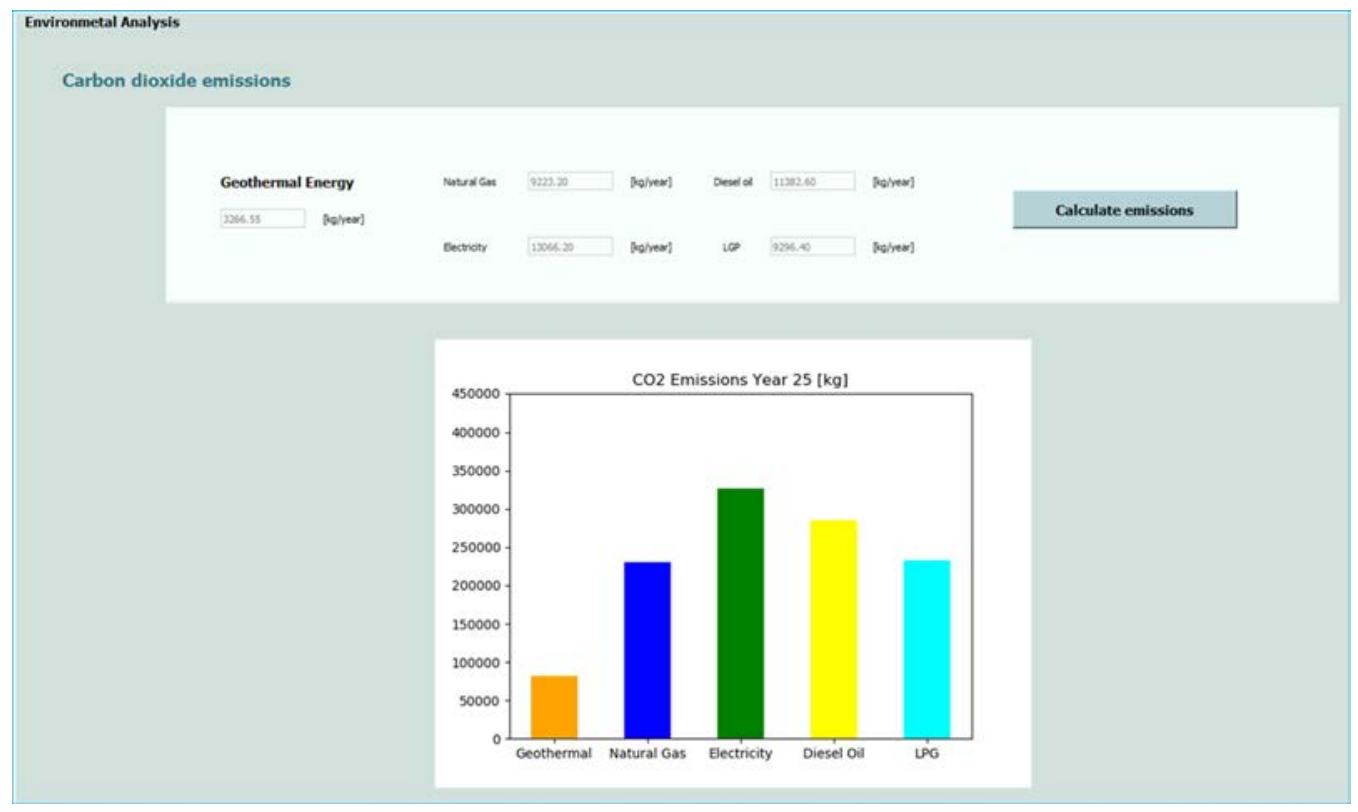

Figure 11 Environmental evaluation of the geothermal system in GES-CAL

geothermal systems; that is to say, a non-specialized user could use it in a simple way.

- For the design of high-power geothermal installations in different regions, EED software is still the best solution for a more precise calculation. The simulation of the fluid temperature plays an essential role in avoiding ground freezing, especially in these high power systems.

- In conclusion, this work emphasizes the need to promote the use of renewable and geothermal energies on the basis of Smart Cities and energy savings. Future works will be directed to the enhancement of the global low enthalpy geothermal systems operation by the search for new alternatives and solutions.

\section{Declaration of competing interest}

We declare that we have no significant competing interests including financial or non-financial, professional, or personal interests interfering with the full and objective presentation of the work described in this manuscript.

\section{Acknowledgements}

The authors thank the CYTED Thematic Network “CIUDADES INTELIGENTES TOTALMENTE INTEGRALES, EFICIENTES Y SOSTENIBLES (CITIES)" no 518RT0558.

\section{Funding}

The author(s) received no financial support for the research, authorship, and/or publication of this article.

\section{Author contributions}

Conceptualization, C.S.B.; methodology, C.S.B. and I.M.N.; validation, D.G.-A. and A.F.M.; formal analysis, C.S.B. and I.M.N.; investigation, C.S.B.; data curation, C.S.B.; writing-original draft preparation, C.S.B.; writing-review and editing, C.S.B. and I.M.N.; supervision, D.G.-A. and A.F.M. All authors have read and agreed to the published version of the manuscript.

\section{Data availability statement}

The authors confirm that the data supporting the findings of this study are available within the article.

\section{References}

[1] A. Casasso and R. Sethi, "Assessment and minimization of potential environmental impacts of ground source heat pump (gshp) systems," Water, vol. 11, no. 8, Jul. 2019. [Online]. Available: https://doi.org/10.3390/w11081573

[2] S. Boahen, K. H. Lee, S. Cho, and J. M. Choi, "A study on the evaluation of the annual energy consumption for a geotermal heat pump system with open loop and closed loop ground heat exchangers," International Journal of Air-Conditioning and Refrigeration, vol. 25, no. 3, Jul. 24, 2017. [Online]. Available: https://doi.org/10.1142/S2010132517500249 
[3] F. D. Longa, L. P. Nogueira, J. Limberger, J. D. V. Wees, and B. V. D. Zwaan, "Scenarios for geothermal energy deployment in europe," Energy, vol. 206, Sep. 1, 2020. [Online]. Available: http://www.techweb.com/se/index.html

[4] A. F. Gheysari, H. M. Holländer, P. Maghoul, and A. Shalaby, "Sustainability, climate resiliency, and mitigation capacity of geothermal heat pump systems in cold regions," Geothermics, vol. 91, Mar. 2021. [Online]. Available: https://doi.org/10.1016/j. geothermics.2020.101979

[5] L. Rybach and M. Mongillo, "Geothermal sustainability - a review with identified research needs," Geothermal Resource Council Transactions, vol. 30, 2006. [Online]. Available: t.ly/eHji

[6] D. Saner and et al., "Is it only co2 that matters? a life cycle perspective on shallow geothermal systems," Renewable and Sustainable Energy Reviews, vol. 14, no. 7, Sep. 2010. [Online]. Available: https://doi.org/10.1016/j.rser.2010.04.002

[7] G. Wang, W. Wang, J. Luo, and Y. Zhang, "Assessment of three types of shallow geothermal resources and ground-source heat-pump applications in provincial capitals in the yangtze river basin, china," Renewable and Sustainable Energy Reviews, vol. 111, Sep. 2019. [Online]. Available: https://doi.org/10.1016/j.rser.2019.05.029

[8] M. Babaei and H. M. Nick, "Performance of low-enthalpy geotermal systems: Interplay of spatially correlated heterogeneity and well-doublet spacings," Applied Energy, vol. 253, Nov. 1, 2019. [Online]. Available: https://doi.org/10.1016/j.apenergy.2019.113569

[9] R. M. Singh, A. K. Sani, and T. Amis, "An overview of ground-source heat pump technology," Managing Global Warming, 2019. [Online]. Available: https://doi.org/10.1016/B978-0-12-814104-5.00015-6l

[10] S. A. Ghoreishi-Madiseh, A. F. Kuyuk, and M. A. D. Brito, "An analytical model for transient heat transfer in ground-coupled heat exchangers of closed-loop geothermal systems," Applied Thermal Engineering, vol. 150, Mar. 5, 2019. [Online]. Available: https://doi.org/10.1016/j.applthermaleng.2019.01.020

[11] X. Song and et al., "Numerical analysis of the heat production performance of a closed loop geothermal system," Renewable Energy, vol. 120, May. 1996. [Online]. Available: https://doi.org/10. 1016/j.renene.2017.12.065

[12] G. Wang and et al., "Heat extraction analysis of a novel multilateral-well coaxial closed-loop geothermal system," Renewable Energy, vol. 163, Ene. 2021. [Online]. Available: https://doi.org/10.1016/j.renene.2020.08.121

[13] K. Nagano, T. Katsura, and S. Takeda, "Development of a design and performance prediction tool for the ground source heat pump system," Applied Thermal Engineering, vol. 26, no. 14-15, Oct. 2006. [Online]. Available: https://doi.org/10.1016/j.applthermaleng.2005. 12.003

[14] X. Li, Z. Chen, and J. Zhao, "Simulation and experiment on the thermal performance of u-vertical ground coupled heat exchanger," Applied Thermal Engineering, vol. 26, no. 14-15, Oct. 2006. [Online]. Available: https://doi.org/10.1016/j.applthermaleng.2005.12.007

[15] Q. Gao, M. Li, and M. Yu, "Experiment and simulation of temperatura characteristics of intermittently-controlled ground heat exchanges," Renewable Energy, vol. 35, no. 6, Jun. 2010. [Online]. Available: https://doi.org/10.1016/j.renene.2009.10.039

[16] J. C. Ríos, "Integration capacity of geothermal energy in supermarkets through case analysis," Sustainable Energy Technologies and Assessments, vol. 34, Ago. 2019. [Online]. Available: https://doi.org/10.1016/j.seta.2019.04.007

[17] H. Skarphagen, D. Banks, B. S. Frengstad, and H. Gether, "Design considerations for borehole thermal energy storage (btes): A review with emphasis on convective heat transfer," Hindawi, vol. 2019, Apr. 22, 2019. [Online]. Available: https://doi.org/10.1155/2019/4961781

[18] C. S. Blázquez, A. F. Martín, P. C. García, L. S. Sánchez, and S. Jiménez, "Analysis of the process of design of a geotermal installation," Renewable Energy, vol. 89, Abr. 2016. [Online]. Available: https://doi.org/10.1016/j.renene.2015.11.067

[19] C. S. Blázquez, A. Farfán-Martín, I. Martín-Nieto, P. Carrasco-García, L. S. Sánchez-Perez, and et al., "Thermal conductivity map of the avila region (spain) based on thermal conductivity measurements of different rock and soil samples," Geothermics, vol. 65, Jun. 2017. [Online]. Available: https://doi.org/10.1016/j.geothermics.2016.09.001

[20] C. S. Blázquez and A. Farfán-Martín and I. Martín-Nieto and P. Carrasco-García and L. S. Sánchez-Perez and et al., "Efficiency analysis of the main components of a vertical closed-loop system in a borehole heat exchanger," Energies, Special Issue Low Enthalpy Geothermal Energy, vol. 10, no. 2, Feb. 10, 2017. [Online]. Available: https://doi.org/10.3390/en10020201

[21] C. S. Blázquez, A. F. Martín, I. M. Nieto, and D. G. Aguilera, "Measuring of thermal conductivities of soils and rocks to be used in the calculation of a geothermal installation," Energies, vol. 10 , no. 6, Jun. 10, 2017. [Online]. Available: https://doi.org/10.3390/ en10060795

[22] C. S. Blázquez and et al., "Analysis and study of different grouting materials in vertical geothermal closed-loop systems," Renewable Energy, vol. 114, no. Parte B, Dic. 2017. [Online]. Available: https://doi.org/10.1016/j.renene.2017.08.011

[23] C. S. Blázquez, D. Borge-Diez, I. M. Nieto, A. F. Martín, and D. González-Aguilera, "Technical optimization of the energy supply in geothermal heat pumps," Geothermics, vol. 81, Sep. 2019. [Online]. Available: https://doi.org/10.1016/j.geothermics.2019.04. 008

[24] C. S. Blázquez, A. F. Martín, I. M. Nieto, D. González-Aguilera, and P. C. García, "Comparative analysis of different methodologies used to estimate the ground thermal conductivity in low enthalpy geothermal systems," Energies, vol. 12, no. 9, May. 2, 2019. [Online]. Available: https://doi.org/10.3390/en12091672

[25] II congreso iberoamericano de ciudades inteligentes, Escuela de Ingenierías del Campus de la UVa, Soria, Esp., 2019.

[26] VDI 4640-2, Thermal use of the underground - Ground source heat pump systems, Verlag des Vereins Deutscher Ingenieure, 2013.

[27] C. S. Bláquez, I. M. Nieto, R. Mora, A. F. Martín, and D. González-Aguilera, "Ges-cal: A new computer program for the design of closed-loop geothermal energy systems," Geothermics, vol. 87, Sep. 2020. [Online]. Available: https: //doi.org/10.1016/j.geothermics.2020.101852

[28] Guía técnica de diseño de sistemas de intercambio geotérmico de circuito cerrado, Asociación Técnica Española de Climatización y Refrigeración (ATECYR), Instituto para la Diversificación y Ahorro de la Energía (IDAE), Madrid, 2012.

[29] Diseño, ejecución y seguimiento de una instalación geotérmica somera. Parte 1: sistemas de circuito cerrado vertical, UNE-EN 100715-1, Asociación Española de Normalización, 2014. [Online]. Available: https://www.une.org/encuentra-tu-norma/ busca-tu-norma/norma?c=N0052899

[30] Eficiencia energética de los edificios. cálculo del consumo de energía para calefacción y refrigeración de espacios, UNE-EN ISO 13790, Asociación Española de Normalización, Nov. 2011. [Online]. Available: https://www.une.org/encuentra-tu-norma/ busca-tu-norma/norma/?c=N0048301 